\title{
Risk Factors for Stunting under Two-Year-Old Children in Surabaya
}

\author{
Cintia Maulina $^{1}$, Riris Diana Rachmayanti ${ }^{1}$ \\ ${ }^{1}$ Faculty of Public Health Universitas Airlangga
}

\section{ABSTRACT}

Background: Indonesia is the fifth-highest number of stunting incidence in the world. Mothers' conditions before, during, and after pregnancy were as major cause of stunting. This study aims to analyze the risk factors of stunting among children under two in Surabaya.

Method: Analytical survey with a cross-sectional design was conducted on 233 selected samples from December 2019 to January 2020. Dataset for the Chisquare test comes from the measurement of the body height of under two-year-old children and interviews with mothers.

Results: It shows that factor related to stunting under two-year-old children in Surabaya is history of Antenatal Care (ANC) during pregnancy ( $p$-value $=0,005)$. Pregnant mother who did non-routine ANC may risk 0,360 times higher to stunting condition. The incidence of stunting in Surabaya is not influenced by factors such as age, education, work status, income, history of Fe and protein consumption. Health office shoud encourage pregnant women to do ANC more than 4 times during pregnancy.

Correspondence

riris.diana@fkm.unair.ac.id

Article History

Received 12 June 2020

Revised 30 September 2020

Accepted 5 January 2021

Available Online 6 January 2021

Keywords

Stunting

Education level

Protein

Fe

DOI

10.14710/jpki.16.1.1-6

\section{INTRODUCTION}

Stunting is a condition in children with a failure to thrive due to chronic malnutrition so that the child's height does not match with age. The stunting condition appeared after the baby turned two years old. The standard of WHOMRGS (Multicenter Growth Reference Study) used to identify the short toddler (stunted) or very short toddler (severely stunted). The Ministry of Health of the Republic of Indonesia categorizes a stunting case as a toddler with a z-score of less than -2SD (stunted) and less than -3SD (severely stunted) ${ }^{1}$.

In 2017 , around $22,2 \%$ of toddlers (150,8 million) in the world suffered from stunting. More than half of that comes from Asia (55\%), while more than a third (39\%) live in Africa. A total of 83,6 million stunting toddlers were in Asia, with the most cases come from South Asia $(58,7 \%)$ and the least from Central Asia $(0,9 \%)^{1}$. At present, Indonesia is one of the countries with a high prevalence of stunting compared to other middle-income countries. Worldwide, Indonesia is a country with the fifth-largest prevalence of stunting. According to the Basic Health Research (Riskesdas) result in 2007, the prevalence of short toddlers in Indonesia was $36,8 \%$. In 2010, there was a slight decline to $35,6 \%$. However, the prevalence of short toddlers increased again in 2013 to $37,2 \%{ }^{1}$. According to
The incidence of stunting in East Java province decreased to $32,18 \%$ compared to 2013 , which was $35,8 \%{ }^{2}$. One of the cities in this province that has stunting is Surabaya. There are two districts in the northern Surabaya with the highest number of stunting, namely Kenjeran (1.594 cases) and Semampir (1.399 cases). Semampir District has an area of $6,65 \mathrm{~km}^{2}$. There are five villages in this district, namely Ampel, Sidotopo, Pegirian, Wonokusumo, and Ujung, with 70 community associations (RW) and 561 neighbourhood associations (RT). Semampir is the third most populous district after Tambaksari and Sawahan ${ }^{3}$. Based on the previously explained background, a study was conducted to analyze the risk factors of stunting on toddlers under two years (baduta) in Semampir District, Surabaya. This research aims to investigate the risk factors, which include age, education level, work status, income, history of Fe consumption, history of ANC, and history of protein consumption in every case of stunting. The dependent variable is the estimator or determinant variable, while the independent variable is the consequence variable ${ }^{4}$.

The dependent variable of this study was the stunting cases which assessed from the child's body length/age. The independent variables were age, education level, work status, income, history of Fe consumption, history of ANC, and history of protein consumption. 


\section{METHOD}

This quantitative research explores how and why stunting can occur with a cross-sectional research approach that studies the dynamics of the correlation between risk factors and effects and observation.

This research was conducted in Wonokusumo village, Semampir district, Surabaya, from December 2019 to January 2020. The population of this research is all the toddlers under two years (baduta) in the Semampir district. The sampling technique used here is non-probability and purposive sampling. Purposive sampling is based on specific considerations made by the researchers themselves, based on the known characteristics of the population ${ }^{4}$. The considerations were made based on the inclusion criteria, including family members, original residents of Semampir District, domiciled for more than five years, raised by the family, and willing to be an informant. The exclusion criteria are physical and mental illness so that the number of 233 mothers were recruited to be respondents.

The types of data collected in this study are primary and secondary data. Primary data was obtained by conducting a survey with respondents using a questionnaire to determine the characteristics of mothers. Besides, to assess stunting, a direct measurement of height is then performed using the stunting nutritional status index, according to the Ministry of Health of Indonesia. Secondary data was obtained from data from the Ampel, Sidotopo, Wonokusumo, and Ujung village, the local health center, the Surabaya health profile report, scientific journals, ebooks, articles, news, and soon.

The description and frequency distribution of each variable was analyzed using Chi-square, which aims to see the strength of the relationship between the independent and the dependent variable. The significance test value for this study is $\alpha=5 \%$. There was a relationship if the p-value (probability value) $\leq 5 \%$, whilst, the results of the study, showed no relationship if the p-value $>5 \%$.

This research has received Ethical Clearance from the Committee of Ethical Approval in the Faculty of Nursing Airlangga University, regarding the protection of Human Rights and welfare in health research with number 1769-KEPK.

\section{RESULT AND DISCUSSION}

There are several health centers (puskesmas) in the Semampir district, namely Ampel, Sidotopo, Wonokusumo, and Ujung. Each puskesmas has its working area. The stunting incidence in the Semampir district is summarized in Table 1, which shows the frequency of stunting from the total sample in the study area. Table 2 shows that 216 mothers of 233 were more than 20 years old. Most mothers have low education elementary and junior high school.
Working status of mothers can be related to free time to care for children properly or not and as many as 175 mothers not working or as housewives. The specified income refers to the minimum wage for Surabaya, which is Rp 4.200.000,-. Based on Table 2, it is found that of 233 families, only 12 families have more than minimum wage income. According to Table 2, the history of $\mathrm{Fe}$ consumption is overall not in good condition because 123 mothers do not consume Fe routinely. However, most mothers did antenatal care (ANC) checks more than four times, and 128 mothers routinely consumed foods containing protein.

Table 1. Overview of stunting cases

\begin{tabular}{lcc}
\hline \multicolumn{1}{c}{ Stunting } & n & \% \\
\hline Yes & 62 & 26,6 \\
No & 171 & 73,4 \\
\hline Total & 233 & 100 \\
\hline
\end{tabular}

Table 2. Frequency distribution of mothers' characteristic

\begin{tabular}{|c|c|c|c|}
\hline Variable & $\mathbf{n}$ & & $\%$ \\
\hline \multicolumn{4}{|l|}{ Age of mother } \\
\hline$\geq 20$ years old & & 216 & 92,7 \\
\hline$<20$ years old & & 17 & 7,3 \\
\hline \multicolumn{4}{|l|}{ Education } \\
\hline Elementary-Junior & High & 177 & 76,0 \\
\hline $\begin{array}{l}\text { School } \\
\text { Senior High } \\
\text { University }\end{array}$ & School- & 56 & 24,0 \\
\hline \multicolumn{4}{|l|}{ Working status } \\
\hline Working & & 58 & 24,9 \\
\hline Not working & & 175 & 75,1 \\
\hline \multicolumn{4}{|l|}{ Income } \\
\hline$\geq \operatorname{Rp} 4.200 .000,-$ & & 12 & 94,8 \\
\hline$<\operatorname{Rp} 4.200 .000,-$ & & 221 & 5,2 \\
\hline \multicolumn{4}{|l|}{ Fe consumption } \\
\hline Yes & & 110 & 47,2 \\
\hline No & & 123 & 52,8 \\
\hline \multicolumn{4}{|l|}{ ANC } \\
\hline$\geq$ four times & & 188 & 80,7 \\
\hline$<$ four times & & 45 & 19,3 \\
\hline \multicolumn{4}{|l|}{ Protein consumption } \\
\hline Yes & & 128 & 54,9 \\
\hline No & & 105 & 45,1 \\
\hline
\end{tabular}

\section{Age of Mother}

The mother's age is related to information and experience gained about problems, especially problems that can affect the health of family members. The results of this study indicate that most mothers aged more than 20 year 
has a p-value 0,164 (larger than $\alpha$ ), which means that there is no relationship between maternal age and the incidence of stunting. Age 20-30 years is a productive period where a person can easily to follow the learning process, and has enough experience and knowledge, especially about providing good complementary food for their children. This study is in line with Lita's research, which states that there is no difference in the age characteristics of parents with stunting ${ }^{6}$. Research conducted at Piyungan shows that there is a relationship between maternal age and the incidence of stunting. Maternal age is associated with age at risk for pregnancy. So, it was concluded that mothers of age at risk had a risk of giving birth to stunting children of $4,08^{7}$.

\section{Education}

Education is one access to gain knowledge, both knowledge about health and others. The higher one's education, the more extensive knowledge will be ${ }^{8}$. Extensive knowledge of the mother makes the mother able to provide proper parenting. The results showed that education $p$-value is 0,627 (larger than $\alpha$ ), which meant that there was no relationship between maternal education and the incidence of stunting. This study is in line with research $^{9}$, which states that parental education is not a risk factor for stunting. Also, research ${ }^{10}$ found that maternal education level was not a factor for stunting because there were many risk factors for stunting. It is contrary to the results of the study ${ }^{11}$, which shows that there is a significant relationship between mother's education level and nutritional status, where mothers with less education have more stunting. Also, research ${ }^{12}$ also shows that there is a relationship between maternal education level and the incidence of stunting among children under five in rural and urban areas. Education can be related to knowledge, which is assumed with higher education the knowledge possessed is increasingly widespread. Low education does not guarantee that a mother does not know about nutrition. The influence is greater than the level of education is a high curiosity to get information about the right food for families, especially for children.

\section{Job Status}

A mother's work status can be related to the time a mother has to care for her child.

Table 3. Cross-tabulation of stunting risk factors for under two years children in Surabaya

\begin{tabular}{|c|c|c|c|c|c|c|c|c|c|}
\hline \multirow[t]{2}{*}{ Variable } & \multicolumn{4}{|c|}{ Stunting } & \multicolumn{2}{|c|}{ Total } & \multirow{2}{*}{$\begin{array}{c}P \\
\text { Value } \\
\left(X_{2}\right)\end{array}$} & \multirow{2}{*}{$\begin{array}{c}95 \% \\
\text { CI }\end{array}$} & \multirow[t]{2}{*}{ OR } \\
\hline & Yes & $\%$ & No & $\%$ & $\mathbf{n}$ & $\%$ & & & \\
\hline \multicolumn{10}{|l|}{ Age of mother } \\
\hline$\geq 20$ years old & 55 & 25,5 & 161 & 74,5 & 216 & 92,7 & \multirow[t]{2}{*}{0,164} & $1,69-1,80$ & \multirow[t]{2}{*}{0,488} \\
\hline$<20$ years old & 7 & 41,2 & 10 & 58,8 & 17 & 7,3 & & $1,33-1,85$ & \\
\hline \multicolumn{10}{|l|}{ Education } \\
\hline Elementary-Junior High & 49 & 27,7 & 128 & 72,3 & 177 & 76,0 & \multirow{3}{*}{0,627} & $1,66-1,79$ & \multirow{3}{*}{1,266} \\
\hline School & & & & & & & & & \\
\hline $\begin{array}{l}\text { Senior High School- } \\
\text { University }\end{array}$ & 13 & 23,2 & 43 & 76,8 & 56 & 24,0 & & $1,65-1,88$ & \\
\hline \multicolumn{10}{|l|}{ Working status } \\
\hline Working & 10 & 17,2 & 48 & 82,2 & 58 & 24,9 & \multirow[t]{2}{*}{0,091} & $1,73-1,93$ & \multirow[t]{2}{*}{0,493} \\
\hline Unemployment & 52 & 29,7 & 123 & 70,3 & 175 & 75,1 & & $1,63-1,77$ & \\
\hline \multicolumn{10}{|l|}{ Family Income } \\
\hline$\geq \operatorname{Rp} 4.200 .000,-$ & 2 & 16,7 & 10 & 83,3 & 12 & 5,1 & \multirow[t]{2}{*}{0,524} & $1,59-2,08$ & \multirow[t]{2}{*}{0,537} \\
\hline$<\operatorname{Rp} 4.200 .000,-$ & 60 & 27,1 & 161 & 72,9 & 221 & 94,9 & & $1,67-1,79$ & \\
\hline \multicolumn{10}{|l|}{ Fe consumption history } \\
\hline Yes & 29 & 26,4 & 81 & 73,6 & 110 & 47,2 & \multirow[t]{2}{*}{1,000} & $1,65-1,82$ & \multirow[t]{2}{*}{0,976} \\
\hline No & 33 & 26,8 & 90 & 73,2 & 123 & 52,8 & & $1,65-1,81$ & \\
\hline \multicolumn{10}{|l|}{ ANC } \\
\hline$\geq$ four times & 42 & 22,3 & 146 & 77,7 & 188 & 81,0 & \multirow[t]{2}{*}{0,005} & $1,72-1,84$ & \multirow[t]{2}{*}{0,360} \\
\hline$<$ four times & 20 & 44,4 & 25 & 55,6 & 45 & 19,0 & & $1,40-1,71$ & \\
\hline \multicolumn{10}{|l|}{ Protein consumption } \\
\hline Yes & 36 & 28,1 & 92 & 71,9 & 128 & 55,0 & \multirow[t]{2}{*}{0,668} & $1,64-1,80$ & \multirow[t]{2}{*}{1,189} \\
\hline No & 26 & 24,8 & 79 & 75,2 & 105 & 45,0 & & $1,67-1,84$ & \\
\hline
\end{tabular}

Information: $X 2=$ Chi Square test; $P^{*}=$ there is a relationship 
The results of this study indicate that the value of $\mathrm{p}$ $(0,091)$ is larger than $\alpha(0,005)$, which means there is no relationship between maternal work status and the incidence of stunting. It is in line with the results of the study ${ }^{14}$, which states that there is a significant relationship between maternal employment status and nutritional status of children under five. The incidence of stunting in four villages located in the Semampir district was common in women who did not work and relate to the low economic status and education of unemployed mothers. These results are consistent with the research ${ }^{15}$ that mothers of children under five who do not work have children who experience more stunting. Research at Wonosari health center shows that there is no relationship between maternal work and the incidence of stunting in toddlers aged 25-59 months. It because working mothers can help in terms of the economy, thereby increasing purchasing power for children's nutritional intake. However, there is less time to care for children than mothers who do not work ${ }^{16}$.

\section{Family Income}

In this study, family income is categorized into higher and less than the minimum wage. The results showed that the value of $p$-value $(0,524)$ is larger than the $\alpha$, which means there is no relationship between family income and the incidence of stunting. It is not following the results of research conducted by (15), which states that there is a relationship between the father's work with the incidence of stunting in children. Also, research in Kanigoro Village, Saptosari, Gunung Kidul, shows that there is a relationship between family income and stunting. The inequality of the results of this study is that stunting is a long-term occurrence of consumption of low-quality food combined with infectious diseases, parenting ${ }^{17}$. Low family income will affect the purchasing power of food so that spending on food is also low ${ }^{18}$.

\section{Fe Consumption History}

Fe tablets serve to assist in the process of formation of haemoglobin in the blood. Iron deficiency in children can cause anaemia and disruption of growth and development. The process of growth and development that is not good can manifest to be stunting. This study shows that the value of $\mathrm{p}(1,000)$ is larger than $\alpha$, which means that there is no relationship between $\mathrm{Fe}$ intake and the incidence of stunting.

It is in line with other studies that state that women who have a history of anaemia in pregnancy are four times at risk for stunting ${ }^{19}$. Iron is one of the essential micronutrients for the human body, which is the most microminerals, which are 3-5 grams. There are several opinions by experts about the role of iron $(\mathrm{Fe})$, namely as an enzyme component, as well as a cytochrome component that influences growth. One of them is a component of the enzyme ribonucleotide reductase, which can participate in DNA synthesis that works indirectly in tissue growth that can affect growth ${ }^{20}$. It is not following research conducted $^{21}$, which states that there is a relationship between iron intake $(\mathrm{Fe})$ with the incidence of stunting.

\section{ANC History}

Antenatal care (ANC) examination aims to optimize the mental and physical health of the mother and baby. The purpose of ANC, especially for mothers, is to face childbirth, preparation for breastfeeding, and the return of reproductive health properly. This study shows that there is a relationship between ANC examination and stunting ( $p$ $=0.005 ; \mathrm{p}>\alpha$ ). The odds ratio value of 0,360 shows that non-routine ANC can risk stunting of 0,360 . The $95 \%$ Confident Internal of ANC is 1,72-1,84. This study is in line with research ${ }^{22,23}$, which shows the relationship between ANC examination and stunting. ANC examination is very important for the prevention and detection of complications or negligence that occurs in pregnancy. Research at Tobelo District Hospital shows that the quality of ANC examination influences the weight of newborns, where a good quality ANC examination has a three times greater chance of giving birth to a baby with healthy birth weight compared to an ANC examination that is not good ${ }^{24}$. Low Birth Weight (LBW) is associated with the incidence of stunting in childrens ${ }^{25,26}$. Also, a history of Low Birth Weight (LBW) raises the risk of 5,6 times the incidence of stunting $^{26}$. It can happen because, from the womb, the baby undergoes growth retardation so that the growth and development of the baby after birth is slower compared to the healthy one ${ }^{28}$.

Other research states there is no correlation between ANC examination and stunting. The reason is that some respondents conduct examinations at the age of the second trimester and third trimester of pregnancy so that the number of ANC does not reach the minimum ANC, namely four visits. Research conducted at Probolinggo shows that the irregularity of pregnant women in conducting antenatal care examinations is because mothers are less aware of the importance of antenatal care. Most mothers visit ANC after pregnancy entering the second and third trimester periods ${ }^{29}$. Nadiyah's study states that routine ANC examinations (equal to or more than four times) cannot determine the nutritional status of pregnant women compared to quality ANC examinations ${ }^{30}$. Table 3 also shows that of the 62 stunting children, 42 of them underwent ANC examination of more than four times, and 29 mothers did not consume $\mathrm{Fe}$ routinely. Thus, regular ANC examination but its consumption of $\mathrm{Fe}$ is not routine, could be the trigger for the occurrence of stunting in children. 


\section{Protein Consumption History}

Protein is one of the macronutrients found in foods, e.g., eggs, milk, meat, poultry, and shellfish. Protein functions as a building block, protein also functions in the body's defence mechanism against various microbes and other toxic substances that come from outside, the protein regulates metabolic processes in the form of enzymes and hormones ${ }^{31}$. The immune system can protect the body from all diseases. A healthy body makes the growth process work accordingly. In this study, the value of $p(0,668)$ is larger than $\alpha(0,05)$ and showed that protein intake was not related to the incidence of stunting. Lack of optimal nutrition and metabolism support does not affect a person's condition acutely. However, there is compelling evidence that nutritional deficiencies have both short-term and longterm effects ${ }^{32}$. Most mothers consume protein foods, but of 128 mothers who consume protein, 29 mothers have stunting children. It can happen because the protein that the mother consumes does not meet her needs, so that the protein does not function properly.

This study is in line with research ${ }^{25}$, which states that children with a protein intake that have less risk of 1,71 times to become stunted, while research ${ }^{33}$ states that there is a relationship between protein intake and stunting. Rahmaniah's research states that a history of energy and protein intake is not related to the incidence of stunting. However, as many as $4,44 \%$ of stunting events can be predicted through a history of energy and protein intake by controlling Upper Arm Circumference (UAC), breastfeeding status, birth weight, and maternal height ${ }^{34}$.

\section{CONCLUSION}

Based on this study, there is a relationship between the history of maternal antenatal care (ANC) with the incidence of stunting in Surabaya. A pregnant mother who did non-routine ANC may risk 0,360 times higher to stunting condition. The incidence of stunting in Surabaya is not influenced by factors such as age, education, work status, income, history of $\mathrm{Fe}$ and protein consumption. Health office should encourage pregnant women to do ANC more than four times during pregnancy. This research needs to examine further other factors that might increase the risk of stunting, such as complementary foods, parenting, disease history, and clean and healthy behaviour.

\section{REFERENCES}

1. Kementerian Kesehatan Republik Indonesia. Buletin Stunting. Vol. 301, Kementerian Kesehatan Republik Indonesia. 2018.

2. Riskesdas. Hasil Utama Riskesdas 2018 Provinsi Jawa Timur. 2018;1-82.

3. Firstianto V, Noviani FH, H ML. Profil Kependudukan Kecamatan Semampir.
2015;(3615100024).

4. Prof. Dr. Suryana Ms. Metodologi Penelitian: Metodologi Penelitian Model Prakatis Penelitian Kuantitatif dan Kualitatif. Universitas Pendidikan Indonesia. 2012. 1-243 p.

5. Astari L, Nasoetion A, Dwiriani C. Hubungan Karakteristik Keluarga, Pola Pengasuhan dan Kejadian Stunting Anak Usia 6-12 Bulan. Media Gizi Kel. 2005;29:40-6.

6. Fajrina N, Syaifudin. Hubungan Faktor Ibu Dengan Kejadian Stunting Pada Balita Di Puskesmas Piyungan Kabupaten Bantul. Fak Ilmu Kesehat Univ 'Aisyiyah Yogyakarta. 2016.

7. Anshori H Al. Faktor Risiko Kejadian Stunting pada Anak Usia 12-24 Bulan (Studi di Kecamatan Semarang Timur). 2013;1-24.

8. Sulistyawati A. Faktor-faktor yang Berhubungan dengan Kejadian Stunting pada Balita. J Ilmu Kebidanan. 2019;5:21-30.

9. Sulastri D. Faktor Determinan Kejadian Stunting pada Anak Usia Sekolah di Kecamatan Lubuk Kilangan Kota Padang. Maj Kedokt Andalas. 2012;36:39-50.

10. Okky Aridiyah, Farah; Rohmawati, Nina; Ririanty M. Faktor-faktor yang Mempengaruhi Kejadian Stunting pada Anak Balita di Wilayah Pedesaan dan Perkotaan ( The Factors Affecting Stunting on Toddlers in Rural and Urban Areas ). eJurnal Pustaka Kesehat. 2015;3.

11. Rakhmawati NZ, Panunggal B. Hubungan Pengetahuan Dan Sikap Ibu Dengan Perilaku Pemberian Makanan Anak Usia 12-24 Bulan. J Nutr Coll. 2014;3(1):43-50.

12. Nisak NZ. Hubungan Pekerjaan Dengan Pengetahuan Gizi Ibu Dengan Status Gizi Balita Desa Duwet Kecamatan Wonosari Kabupaten Klaten. Univ Muhammadiyah Surakarta. 2018;10-1.

13. Anisa P. Faktor-Faktor yang Berhubungan dengan Kejadian Stunting Pada Balita Usia 25-60 Bulan di Kelurahan Kalibaru Depok Tahun 2012. Univ Indones [Internet]. 2012;1-125. Available from: lib.ui.ac.id/file?file=digital/20320460-S-Paramitha Anisa.pdf

14. Agustiningrum T. Hubungan Karakteristik Ibu Dengan Kejadian Stunting PAda Balita Usia 24-59 Bulan Di Wilayah Kerja Puskesmas Wonosari I. Univ 'Aisyiyah Yogyakarta. 2016.

15. Sri, Mugianti; Mulyadi, Arif; Khoirul Anam,Agus; Lukluin Najah Z. Faktor Penyebab Anak Stunting Usia 25-60 Bulan di Kecamatan Sukorejo Kota Blitar. J Ners dan Kebidanan. 2018;5:268-78.

16. Venuz P, Lema V, Setiono KW, Manubulu RM. Analisis Faktor Risiko Kejadian Stunting pada Balita di Wilayah Kerja Puskesmas Oepoi. Cendan Med J. 2019;17(3).

17. Widyaningrum DA, Romadhoni DA. Riwayat Anemia 
Kehamilan dengan Kejadian Stunting pada Balita di Desa Ketandan Dagangan Madiun. Medica Majapahit. 2018;10(2).

18. Duggan C, Watkins JB, Allan Walker W. Nutrition in Pediatrics: Basic Science, Clinical Applications [Internet]. London; 2008. 923 p. Available from: https://books.google.co.id/books/about/Nutrition_in_P ediatrics.html?id=wSTISCdSIosC\&redir_esc =y

19. Oktavitatimur Islami D. Hubungan Asupan Zat Besi (Fe) dengan kejadian Stunting pada Anak Sekolah Dasar di Madrasah Ibtidaiyah Muhammadiyah Kartasura 2017. 2018.

20. Hutasoit M, Utami KD, Afriyliani NF. Kunjungan Antenatal Care Berhubungan dengan Kejadian Stunting. 2018;2.

21. Amini A. Hubungan Kunjungan Antenatal Care (ANC) dengan Kejadian Stunting pada Balita Usia 1259 Bulan di Kabupaten Lombok Utara Provinsi NTB Tahun 2016. 2016;2-22. Available from: file://C:/Users/Acer/Downloads/anc.pdf

22. Ruindungan RY, Kundre R, Masi G. Hubungan Pemeriksaan Antenatal Care (Anc) Dengan Kejadian Berat Badan Lahir Rendah (BBLR) Di Wilayah Kerja Rsud Tobelo. J Keperawatan. 2017;5(1).

23. Vaozia S. Faktor Risiko Kejadian Stunting Pada Anak Usia 2-3 Tahun (Studi di Kecamatan Semarang Timur). J Nutr Coll. 2013;2(4):523-30.

24. Nasution D, Nurdiati DS, Huriyati E. Berat badan lahir rendah (BBLR) dengan kejadian stunting pada anak usia 6-24 bulan. J Gizi Klin Indones. 2014;11(1):31.

25. Fitri L. Hubungan BBLR Dan Asi Ekslusif Dengan Kejadian Stunting Di Puskesmas Lima Puluh
Pekanbaru. J Endur. 2018;3(1):131.

26. Proverawati A IC. Berat Badan Lahir Rendah (BBLR). Yogyakarta: Nuha Medika; 2010.

27. Nurmasari V, Sumarmi S. Hubungan Keteraturan Kunjungan Antenatal Care dan Kepatuhan Konsumsi Tablet Fe dengan Kejadian Anemia pada Ibu Hamil Trimester III di Kecamatan Maron Probolinggo Relation between Regularity of Antenatal Care Visits and Compliance of Iron Tablets Consumpti. 2019 [Internet]. 2019;46-51. Available from: file://C:/Users/ASUS/Downloads/10446-41963-4PB.pdf

28. Nadiyah, Briawan D, Martianto D. Faktor Risiko Stunting Pada Anak Usia 0-23 Bulan Di Provinsi Bali, Jawa Barat, Dan Nusa Tenggara Timur. J Gizi dan Pangan. 2014;9(2):125-32.

29. Diana FM. Fungsi dan Metabolisme Protein dalam Tubuh Manusia. J Kesehat Masy. 2009;4(1):47-52.

30. Verbruggen SCAT. Protein, Energy and Their Interaction in Critically Ill Children. Netherlands: Optima Grafische Communicate; 2010. 233 p.

31. Ayuningtyas A, Simbolon D, Rizal A. Asupan Zat Gizi Makro dan Mikro terhadap Kejadian Stunting pada Balita. J Kesehat. 2018;9(3):445.

32. Rahmaniah R, Huriyati E, Irwanti W. Riwayat Asupan Energi dan Protein yang Kurang Bukan Faktor Risiko Stunting pada Anak Usia 6-23 bulan. J Gizi dan Diet Indones (Indonesian J Nutr Diet. 2016;2(3):150. 